\title{
Abdominal distension in female patients with irritable bowel syndrome: exploration of possible mechanisms
}

\author{
D G Maxton, D F Martin, P J Whorwell, M Godfrey
}

\begin{abstract}
Abdominal distension is a common but little understood symptom of the irritable bowel syndrome. The authenticity of the symptom was confirmed by appreciable increases in girth measurement during the day in 20 patients with the irritable bowel syndrome compared with 20 control subjects. Objective corroboration of this finding was shown in the group with the irritable bowel syndrome by a highly significant increase in lateral abdominal 'profile' on computed tomography. Previously postulated mechanisms for distension namely, retention of gas, depression of the diaphragm, and excess lumbar lordosis - were excluded by the radiological findings. Voluntary protrusion of the abdomen produced a completely different pattern on computed tomography to that observed in the irritable bowel syndrome. These observations suggest that abdominal distension may be related to changes in motility or tone of gastrointestinal smooth muscle.
\end{abstract}

Abdominal distension is one of the principal features of irritable bowel syndrome..$^{1-3}$ Characteristically, patients report that distension is absent in the morning and progressively appears during the day with eating being the most frequent exacerbating factor. ${ }^{4}$ The cause is entirely unclear and many question whether it is even a real phenomenon. Explanations to account for this symptom include excessive intraabdominal gas, depression of the diaphragm, increased lumbar lordosis, and voluntary protrusion of the abdomen. ${ }^{46}$ There has been little or no investigation of the subject, however, not even to the extent of documenting whether girth does actually alter during the day.

It was the purpose of this study to confirm or refute the existence of abdominal distension by objective measurements and then examine possible mechanisms with the aid of computed tomography.

Departments of Medicine and Radiology,

University Hospital of

South Manchester, Nell

Lane, West Didsbury,

Manchester M20 8LR

D G Maxton

D F Martin

P J Whorwell

$M$ Godfrey

Correspondence to:

Dr P J Whorwell.

Accepted for publication

3 August 1990

\section{Patients and methods}

Twenty consecutive female outpatients with the irritable bowel syndrome (age range 20-65 years) participated in the study. The 15 premenopausal patients were studied in the follicular phase of the menstrual cycle. The diagnosis of the irritable bowel syndrome was based on the presence of abdominal pain, abdominal distension, and a disordered bowel habit in the absence of other gastrointestinal pathology. Patients were starved from midnight and studied at 830 am and again at $430 \mathrm{pm}$ on the same day, with care being taken to ensure that the single midday meal allowed was the same calorific value and fibre content. The following investigations were performed on both occasions:

Abdominal girth, measured at three anatomical levels lying and standing. Position A: midway between the xiphisternum and the umbilicus. Position B: at the level of the umbilicus. Position $\mathrm{C}$ : midway between the umbilicus and the symphysis pubis.

Computed tomography. Using an electronic 'region of interest' pen on the scanner console to draw over projected anteroposterior and lateral computed tomographic 'Scout' views, an abdominal 'profile' was derived by outlining the periphery of the entire abdominal cavity (Figure). In addition, the amount of intra-abdominal gas was assessed by drawing round all gas shadows in both projections (Figure). Diaphragmatic position was measured relative to the vertebral column.

Lumbar lordosis. Using lateral standing plain $x$ ray images, the angle between lines perpendicular to the upper border of the first and lower border of the fifth lumbar vertebra was calculated.

Patients were also weighed at both times to assess whether fluid retention could be contributory.

Twenty control subjects matched for age and sex were assessed in exactly the same way in terms of abdominal girth, but it was not thought ethically justifiable to submit this group to radiology.

\section{STATISTICAL ANALYSIS}

The girth measurements were found to have a non-normal distribution so were analysed using non-parametric methods. A Mann-Whitney U test was performed on the morning (am) measurements to evaluate the initial difference between the control subjects and the irritable bowel syndrome patients. The same test was then used to compare the groups with respect to change in girth (pm minus am). Changes in the computed tomographic data and lumbar lordosis in the irritable bowel syndrome patients were assessed by repeated measures analyses of variance. The gas volume values were found to follow log-normal distributions so were converted to natural logarithms for evaluation. Summary statistics have been detransformed into the original units for presentation, hence the averages reported are geometric means and the diurnal changes are the ratios of the pm to the am readings. 


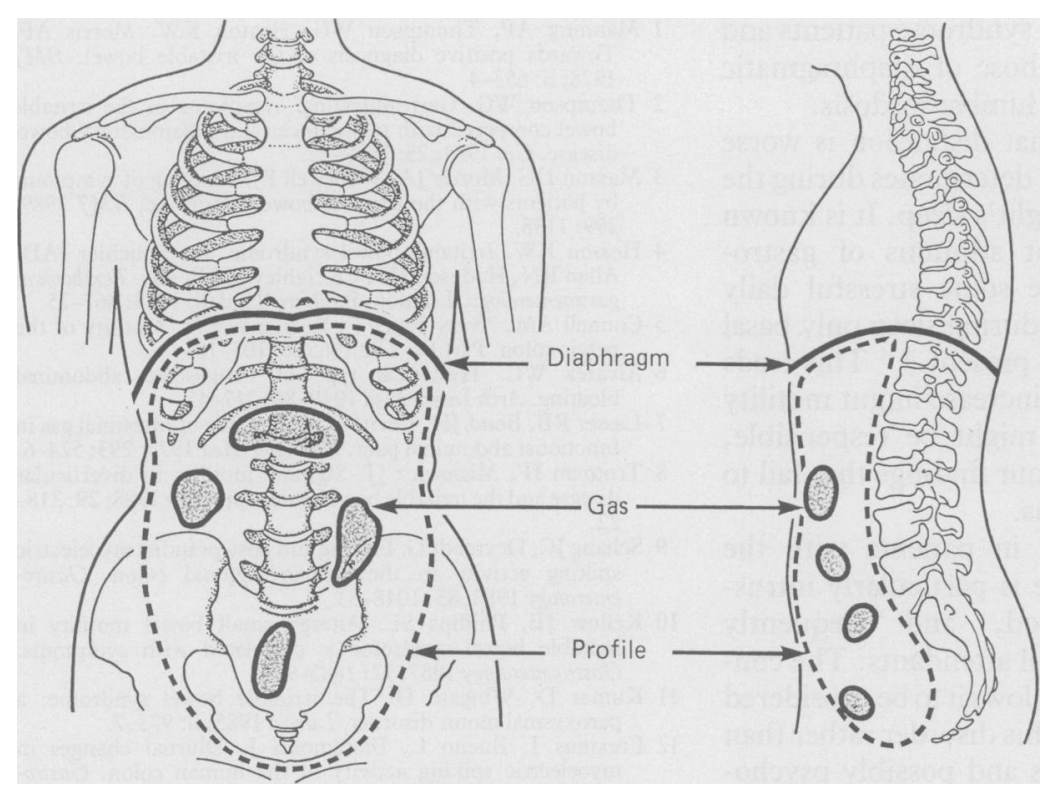

Diagrammatic representation of abdominal 'profile' and intra-abdominal gas measurements.

\section{Results}

In the patients with the irritable bowel syndrome abdominal girth significantly increased during the day at all three anatomical levels both in the lying and standing positions (Table I). This increase in girth was also significant when compared with controls, who experienced negligible change. There was no difference between the patients and control subjects in initial girth measurements.

TABLE I Girth measurements (cm) lying and standing

\begin{tabular}{|c|c|c|c|c|c|c|}
\hline & \multicolumn{3}{|c|}{$\begin{array}{l}\text { Irritable bowel syndrome patients } \\
\text { Median ( } 95 \% \text { confidence intervals) }\end{array}$} & \multicolumn{3}{|c|}{$\begin{array}{l}\text { Control subjects } \\
\text { Median ( } 95 \% \text { confidence intervals) }\end{array}$} \\
\hline & $a m$ & \multicolumn{2}{|l|}{$p m$} & \multicolumn{2}{|l|}{$a m$} & $p m$ \\
\hline \multicolumn{7}{|c|}{$\begin{array}{l}\text { Girth measurements: } \\
\text { Position 1: }\end{array}$} \\
\hline $\begin{array}{l}\text { Lying } \\
\text { Standing }\end{array}$ & $\begin{array}{l}82.0(78 \text { to } 87) \\
81.0(75 \text { to } 85)\end{array}$ & \multirow{2}{*}{\multicolumn{2}{|c|}{$\begin{array}{l}84 \cdot 5(77 \text { to } 90) \\
84 \cdot 0(79 \text { to } 90)\end{array}$}} & \multirow{2}{*}{\multicolumn{2}{|c|}{$\begin{array}{l}73 \cdot 5(69 \text { to } 80) \\
74 \cdot 0(69 \text { to } 79)\end{array}$}} & $\begin{array}{l}74 \cdot 0(69 \text { to } 81) \\
74 \cdot 0(70 \text { to } 80)\end{array}$ \\
\hline \multicolumn{4}{|l|}{ Position 2: } & & & \\
\hline $\begin{array}{l}\text { Lying } \\
\text { Standing }\end{array}$ & $\begin{array}{l}86 \cdot 5(82 \text { to } 90) \\
86 \cdot 5(83 \text { to } 93)\end{array}$ & \multicolumn{2}{|c|}{$\begin{array}{l}89 \cdot 5(85 \text { to } 94) \\
93.0(89 \text { to } 97)\end{array}$} & \multicolumn{2}{|c|}{$\begin{array}{l}83 \cdot 0(74 \text { to } 89) \\
83 \cdot 5(71 \text { to } 91)\end{array}$} & $\begin{array}{l}83 \cdot 5(74 \text { to } 89) \\
84 \cdot 5(72 \text { to } 92)\end{array}$ \\
\hline \multirow{3}{*}{$\begin{array}{l}\text { Position 3: } \\
\text { Lying } \\
\text { Standing }\end{array}$} & & & & & & \\
\hline & $\begin{array}{l}93 \cdot 5(91 \text { to } 95) \\
94 \cdot 0(92 \text { to } 101)\end{array}$ & \multicolumn{2}{|c|}{$\begin{array}{l}95 \cdot 5(92 \text { to } 100) \\
99 \cdot 0(95 \text { to } 102)\end{array}$} & \multicolumn{2}{|c|}{$\begin{array}{l}89 \cdot 0(82 \text { to } 93) \\
90 \cdot 0(82 \text { to } 98)\end{array}$} & $\begin{array}{l}89 \cdot 5(81 \text { to } 94) \\
91 \cdot 5(83 \text { to } 98)\end{array}$ \\
\hline & \multicolumn{2}{|c|}{$\begin{array}{l}\text { Irritable bowel syndrome patients } \\
\text { Difference }(95 \% \mathrm{CI})\end{array}$} & $\begin{array}{l}\text { Controls } \\
\text { Differen }\end{array}$ & $5 \% C I)$ & \multicolumn{2}{|c|}{$\begin{array}{l}\text { Significance } \\
\text { Irritable bowel syndrome } \\
\text { v control }\end{array}$} \\
\hline \multicolumn{7}{|c|}{$\begin{array}{l}\text { Median difference in girth measurement ( } a m \mathrm{v} p m) \text { : } \\
\text { Position } 1 \text { : }\end{array}$} \\
\hline Lying & \multirow{2}{*}{\multicolumn{2}{|c|}{$\begin{array}{l}2.5(1.0 \text { to } 3.5) \\
3.5(1.5 \text { to } 5.0)\end{array}$}} & $\begin{array}{l}0(0 \text { to } 0 \\
0(0 \text { to } 0\end{array}$ & \multicolumn{3}{|c|}{$\begin{array}{l}\mathrm{p}=0.0015 \\
\mathrm{p}<0.0001\end{array}$} \\
\hline \multicolumn{5}{|l|}{ Position 2: } & & \\
\hline $\begin{array}{l}\text { Lying } \\
\text { Standing }\end{array}$ & \multicolumn{2}{|l|}{$\begin{array}{l}3 \cdot 5(1 \cdot 0 \text { to } 5 \cdot 5) \\
4 \cdot 0(2 \cdot 5 \text { to } 7 \cdot 0)\end{array}$} & $\begin{array}{l}0(0 \text { to } 0) \\
0(0 \text { to } 0\end{array}$ & \multicolumn{3}{|c|}{$\begin{array}{l}\mathrm{p}=0 \cdot 0001 \\
\mathrm{p}<0 \cdot 0001\end{array}$} \\
\hline \multicolumn{7}{|l|}{ Position 3: } \\
\hline $\begin{array}{l}\text { Lying } \\
\text { Standing }\end{array}$ & \multicolumn{2}{|l|}{$\begin{array}{l}2.0(1.0 \text { to } 3.0) \\
3.0(1.0 \text { to } 4.5)\end{array}$} & $\begin{array}{l}0(0 \text { to } 0 \\
0(0 \text { to } 1\end{array}$ & \multicolumn{3}{|c|}{$\begin{array}{l}p=0.0002 \\
p=0.003\end{array}$} \\
\hline
\end{tabular}

There was a large and highly significant change in lateral abdominal 'profile' on computed tomography during the day (Table II). No change was observed in the anteroposterior profile, but this would be expected as abdominal distension mainly occurs by forward protrusion of the abdominal wall. In both planes there was a slight, but non-significant, increase in intraabdominal gas over the day. There was no significant difference in diaphragmatic position in the morning compared with the afternoon.

Eight subjects experienced a slight increase in lumbar lordosis while in seven it decreased and was unchanged in the remainder. A change in abdominal girth did not correlate in any way with change in lumbar lordosis.

No change in body weight was observed over the day.

\section{Discussion}

This study confirms that compared with healthy control subjects patients with irritable bowel syndrome develop pronounced abdominal distension during the day as shown by both direct and radiological measurement.

The accumulation of abdominal gas is often suggested as a possible mechanism of distension. This study failed to find any evidence of appreciably increased amounts of abdominal gas or its apparent redistribution. This observation is consistent with a previous study using a dilution technique which suggested that patients with the irritable bowel syndrome do not retain excessive gas. $^{7}$

Alvarez,${ }^{6}$ in the only previous systematic study of distension, also recognised that excess gas did not seem to have a role in this symptom. He suggested that increased lumbar lordosis may account for the phenomenon in some of his subjects. In our study some patients showed a tendency to hyperextend the lumbar spine but no consistent findings emerged, and there was no correlation with the degree of distension. In addition, there was no noticeable change in position of the diaphragm. Thus we have been unable to find support for any of the mechanisms which hitherto have been suggested to account for this phenomenon.

Voluntary protrusion of the abdomen has to be considered as a possibility, particularly in the irritable bowel syndrome where psychological factors are sometimes implicated. To assess this aspect a series of subjects were asked to voluntarily protrude their abdomens while undergoing computed tomography for other reasons. The pattern observed was completely different from

TABLE II Computed tomographic measurement for irritable bowel syndrome patients

\begin{tabular}{|c|c|c|c|c|c|}
\hline Measurement $\left(\mathrm{cm}^{2}\right)$ & $\begin{array}{l}\text { am mean }(95 \% \\
\text { confidence intervals) }\end{array}$ & $\begin{array}{l}\text { pm mean } 95 \% \\
\text { confidence intervals) }\end{array}$ & $\begin{array}{l}\text { Change (pm-am) } \\
\text { (95\% confidence } \\
\text { intervals) }\end{array}$ & $\begin{array}{l}\text { Ratio ( } \mathrm{pm} / \mathrm{am}) \\
\text { (95\% confidence } \\
\text { intervals) }\end{array}$ & $\begin{array}{l}\text { Significance } \\
\text { am } \mathrm{v} \mathrm{pm}\end{array}$ \\
\hline $\begin{array}{l}\text { Anteroposterior } \\
\text { 'profile' }\end{array}$ & $\begin{array}{l}754 \\
(722 \text { to } 786)\end{array}$ & $\begin{array}{l}749 \\
(720 \text { to } 778)\end{array}$ & $\begin{array}{l}-5 \\
(-39 \text { to } 29)\end{array}$ & - & $\mathrm{p}=0.75$ \\
\hline Lateral 'profile' & $\begin{array}{l}235 \\
\text { (218 to } 252 \text { ) }\end{array}$ & $\begin{array}{l}260 \\
(244 \text { to } 276)\end{array}$ & $\begin{array}{l}25 \\
(12 \text { to } 37)\end{array}$ & - & $\mathrm{p}=0.0009$ \\
\hline $\begin{array}{l}\text { Anteroposterior gas } \\
\text { volume }^{\star}\end{array}$ & $\begin{array}{l}56 \cdot 1 \\
(37 \text { to } 84)\end{array}$ & $\begin{array}{l}64 \cdot 5 \\
(43 \text { to } 96)\end{array}$ & & $\begin{array}{l}1.15 \\
(0.96 \text { to } 1.37)\end{array}$ & $p=0 \cdot 11$ \\
\hline Lateral gas volume ${ }^{\star}$ & $\begin{array}{l}29 \cdot 3 \\
(22 \text { to } 40)\end{array}$ & $\begin{array}{l}32 \cdot 5 \\
(23 \text { to } 46)\end{array}$ & $3 \cdot 2$ & $\begin{array}{l}1 \cdot 11 \\
(0.92 \text { to } 1.33)\end{array}$ & $\mathrm{p}=0.25$ \\
\hline
\end{tabular}

${ }^{\star}$ Geometric means for am and pm thus significance of changes (am $\left.v \mathrm{pm}\right)$ based on ratios. 
that in the irritable bowel syndrome patients and the changes seen were those of diaphragmatic depression and increased lumbar lordosis.

Most patients claim that distension is worse after meals, progressively deteriorates during the day, and settles after a night's sleep. It is known that meals are a potent stimulus of gastrointestinal motility as are some stressful daily activities. ${ }^{8-12}$ Conversely, during sleep only basal interdigestive motility is present. ${ }^{12} 13$ This leads to the possibility that an increase in gut motility or smooth muscle tone might be responsible, especially in the light of our findings that fail to support other mechanisms.

Abdominal distension in patients with the irritable bowel syndrome is particularly intrusive, ${ }^{3}$ poorly understood, and frequently dismissed by their medical attendants. The confirmation of its existence allows it to be considered as a legitimate feature of this disorder rather than as a symptom of dubious and possibly psychological origin.

We thank Mrs Julie Morris for statistical analyses and advice.
1 Manning AP, Thompson WG, Heaton KW, Morris AF. Towards positive diagnosis of the irritable bowel. $B M \dot{F}$ 1978; ii: $653-4$

2 Thompson WG. Gastrointestinal symptoms in the irritable bowel compared with peptic ulcer and inflammatory bowel disease. Gut 1984; 25: 1089-92.

3 Maxton DG, Morris JA, Whorwell PJ. Ranking of symptoms by patients with the irritable bowel syndrome. $B M \mathcal{F} 1989$; 299: 1138 .

4 Heaton KW. Irritable bowel syndrome. In: Bouchier IAD, Allan RN, Hodgson HSF, Keighley MRB, eds. Textbook of Allan RN, Hodgson HSF, Keighley MRB, eds. Textbook of

5 Connell AM, Avery Jones F, Rowlands EN. Motility of the pelvic colon. Part IV. Gut 1965; 6: 105-12.

6 Alvarez WC. Hysterical type of nongaseous abdominal bloating. Arch Intern Med 1949; 84: 217-45.

7 Lasser RB, Bond JH, Levitt MD. The role of intestinal gas in functional abdominal pain. $N$ Engl $\mathcal{Y}$ Med 1975; 293: 524-6.

8 Trotman IF, Misiewicz JJ. Sigmoid motility in diverticular disease and the irritable bowel syndrome. Gut 1988; 29: 21822.

9 Schang JC, Devroede G. Fasting and post-prandial myoelectric spiking activity in the human sigmoid colon. Gastrospiking activity in the hum

10 Kellow JE, Phillips SF. Altered small bowel motility in irritable bowel syndrome is correlated with symptoms. Gastroenterology 1987; 92: 1885-93.

11 Kumar D, Wingate D. The irritable bowel syndrome: a paroxysmal motor disorder. Lancet 1985; ii: 973-7.

12 Frexinos J, Bueno L, Fioramonti J. Diurnal changes in myoelectric spiking activity of the human colon. Gastroenterology 1985; 88: 1104-10.

13 Narducci F, Bassotti G, Gaburri M, Morelli A. Twenty four hour manometric recording of colonic motor activity in healthy man. Gut 1987; 28: 17-25. 